\title{
Developing Sukh-Beas as a potential recharge site during wet years for Bari Doab
}

\author{
Muhammad Basharat ${ }^{1}$ (1) $\cdot$ Maham Basharat $^{2}$
}

Received: 19 June 2019 / Accepted: 16 September 2019 / Published online: 28 September 2019

(c) The Author(s) 2019

\begin{abstract}
Bari Doab is depleting the most in groundwater and therefore needs to be recharged. This paper presents a possibility of recharging Bari Doab through the abandoned Sukh-Beas channel. For this purpose, 25 cross sections were taken and ten infiltration tests were performed. Three different HEC-RAS models were run to find its channel capacity at different reaches. The infiltration capacity of the Sukh-Beas Nallah was found to be a total of about $808 \mathrm{cfs}$, which can be used to recharge the groundwater, after some necessary steps have been taken to improve the infrastructure.
\end{abstract}

Keywords Recharge $\cdot$ Bari-Doab $\cdot$ Sukh-Beas

\section{Introduction}

Depleting in lower and central parts of the Bari Doab, increasing deficit between groundwater recharge and extraction by tube well is causing groundwater depletion to the tune of about $0.15-0.55 \mathrm{~m}$ per year. However, the situation in other areas of Punjab is comparatively better (Figs. 1,2). Sixty-five percent area of Bari Doab has depth to water table (DTW) of more than $12 \mathrm{~m}$, whereas maximum DTW has reached up to $24 \mathrm{~m}$ in the lower parts of Bari Doab (Basharat 2016).

The conditions are getting worse with the passage of time even in agricultural areas of Bari Doab, i.e., in October 2014, an area of $86.41 \%$ had DTW of more than $600 \mathrm{~cm}$. Also, $59.1 \%$ of the total area had DTW of more than $1200 \mathrm{~cm}$, as shown in Fig. 2. Another relatively severe impact of groundwater depletion is the quality deterioration of groundwater being pumped by the farmers, particularly in central depleted areas of the Doab, where deeper groundwater has higher salt contents as compared to shallow groundwater (Fig. 3), seeped after inception of the irrigation system. Ensuing to groundwater depletion, pumping costs have increased about

Muhammad Basharat

basharatm@hotmail.com

1 International Waterlogging and Salinity Research Institute (IWASRI) WAPDA, Lahore, Pakistan

2 Fast NUCES, Lahore, Pakistan
3-5 times due to the deepening of pump sumps and conversion from centrifugal to turbine pumps (Basharat 2012).

\section{Moving toward sustainable use of groundwater}

If declining water table is the manifestation of unsustainable use of groundwater, arresting the decline and recharging the groundwater are the only means to restore sustainability to the system. Alternate cropping and improving efficiency of irrigation water can check the receding water table. Also, use of surplus canal water during the rainy season to recharge the aquifers may be of some help in reversing the trend. No single approach can reverse such a large negative groundwater balance as is observed in Bari Doab. In Pakistan, there is a strong relationship between groundwater irrigation, food security and the livelihoods of the population dependent on it. Therefore, there is a dire need to stabilize or even improve the groundwater levels in Bari Doab.

Also, the diversion of surplus surface water to groundwater storage appears to offer the most favorable prospects for control below Kotri wastage of our precious resource in the absence of any surface storages to be added in near future. The alluvial aquifer that underlies Punjab is ideal for the purpose in nearly all respects (Greenman et al. 1967). It is favorably situated with respect to both the availability of recharge and areas of use of water, and there are no extensive geologic barriers to recharge or to circulation within the aquifer. The storage capacity of the groundwater reservoir is equal to many times the annual flow of the Indus River 


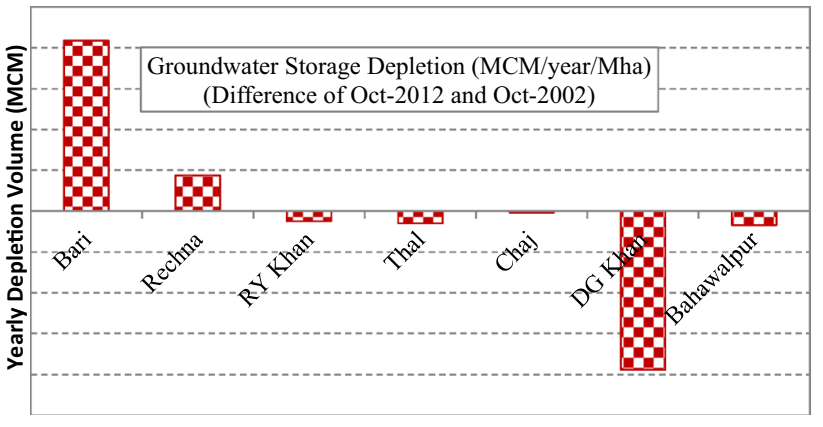

Fig. 1 Comparison of groundwater depletion rates among regions in Punjab

system. Moreover, the groundwater reservoir has infinite life because the groundwater storage is free of sediments. The groundwater reservoir can be replenished according to the availability of surface water for recharge, and the reservoir can be tapped according to the demand for water without regard to seasonal or annual variations in river flows.

\section{Sukh-Beas River}

The actual Beas River originates in the northern part of India. The river rises in the Himalayas in central Himachal Pradesh, India, and flows for about $470 \mathrm{~km}$ to the Sutlej River in the Indian state of Punjab. Its drainage basin is $20,303 \mathrm{~km}^{2}$. The popular story about the Beas River is that till the end of eighteenth century, it flowed down this nallah (instead of joining Sutlej River near Ferozepur) and joined the Rohi Nallah (old Sukh-Beas) as it entered Pakistan at Taraga Post adjacent to RD: 476 of BRBD canal and discharged into the Sutlej River reach which belongs to Pakistan, before Ferozepur Headworks. Till 1960s or 70 s, the Kasur Nallah flowed down along the city of Kasur (Basharat 2016) toward Chunian and then traversed almost in the middle of Bari Doab, in a sinusoidal fashion, till its ultimate confluence with Chenab River near Jalalpur Pirwala. In order to avoid frequent flooding in Kasur and downstream areas, the government diverted the Kasur Nallah to Sutlej River on the Pakistani side of the border, near Kasur-Khem Karan road. Before this, BRBD canal used

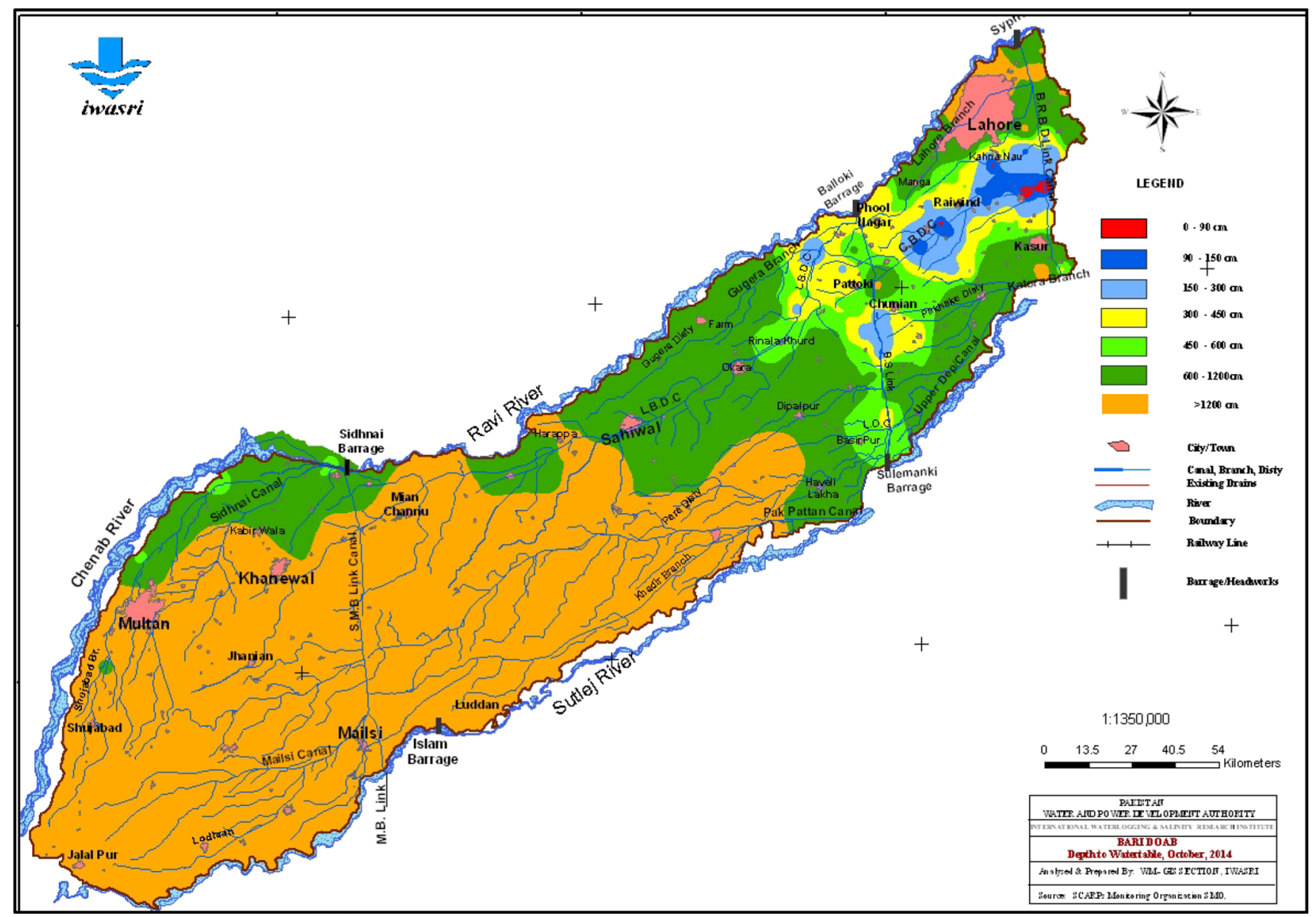

Fig. 2 Depth to water table position in Bari Doab, post-monsoon 2014 (prepared by Dilbar Hassan, SRO, IWASRI) 


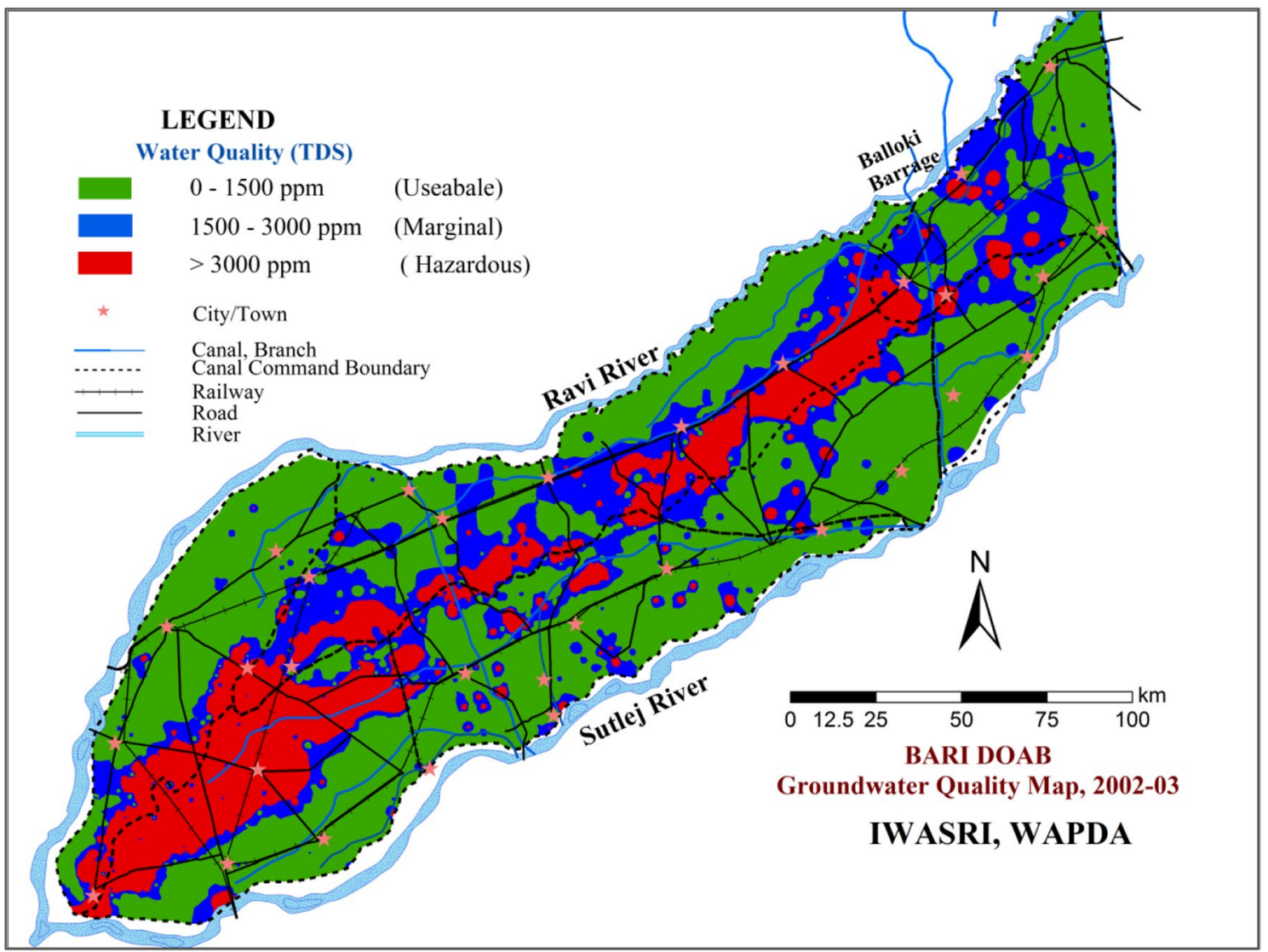

Fig. 3 Groundwater quality variation in Bari Doab, during 2002-2003

to pass as a siphon under the Kasur Nallah. The diverted channel completely passes along the Pakistani side of the international borders and joins Sutlej River upstream of Ferozepur Barrage, which is in India.

Therefore, nowadays the Sukh-Beas has no catchment across Indian borders and only carries drainage water of the adjacent lands of Bari Doab from Kasur district. In the past, it used to cross into Pakistan from India (called Rohi Nallah) and brought heavy flood flows, but now its natural course (BRBD crosses as a siphon at RD496) has been diverted to Sutlej River along the left side of the Bambanwala-RaviBedian-Depalpur (BRBD) Link canal. Now, the remaining Sukh-Beas starts from downstream of BRBD canal. In Pakistan, most of its bed remains dry except upper reaches receiving drainage from adjacent villages and factories. The flow reduces in the $\mathrm{d} / \mathrm{s}$ direction due to infiltration under the bed.

Previously, the BRBD canal flowed under this old SukhBeas channel as a siphon at RD: 496 of BRBD. Nowadays, the BRBD passes this site as an open channel with a slight curve. The Rohi Nallah (written as Kasur Nallah on Google Maps, showing it as passing through the Batala city, while coming from Gurdaspur) originates adjacent to Beas River.
A field tour was carried out to confirm the existing route and flows in the Rohi Nallah, on December 02, 2014. A discharge of 200-400 cusecs was judged as flowing in the nallah. (Channel prism is irregular, and therefore it is difficult to assess the discharge.) According to the local people, the Rohi Nallah flows round the year. Wherever possible, the farmers pump surface water for irrigating the adjoining lands. This pumped water costs about $70 \%$ of the groundwater pumping cost. Flood is observed every year in the Rohi Nallah. According to a farmer, who also guided in the area, polluted water was normally observed as flowing in the Rohi Nallah until 2000. But since then, freshwater flows round the year. Keeping in view that India completed Thein Dam on Ravi River in 2000, it is postulated that from 2000 onward, this Rohi Nallah is being used as a link channel to divert flows from Ravi to Ferozepur Headworks.

The Sukh-Beas Nallah is located in the center and along the entire length of the Bari Doab. It is the main surface water drainage channel in the area which has a length of 535 miles. The northwestern boundary of its catchment basin is formed by the Central Bari Doab Canal, the Lower Bari Doab Canal and the Haveli Canal and the southeastern boundary by the Dipalpur Canal, the Pakpattan Canal and 


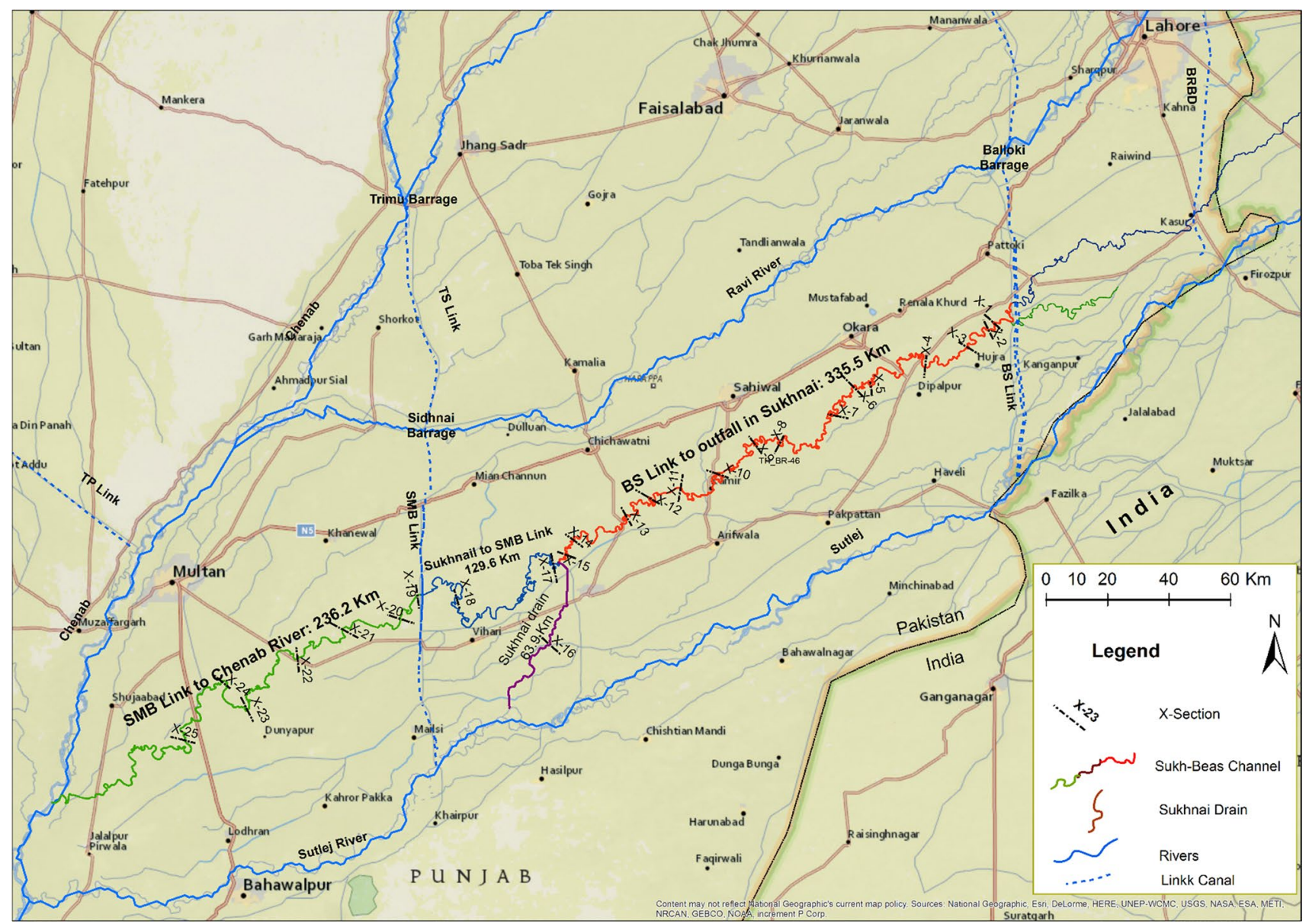

Fig. 4 Sukh-Beas channel passing through the center of Bari Doab

the Mailsi Canal. The area in between is under the command of innumerable branch canals, distributaries, minors, sub-minors and watercourses which irrigate the entire catchment basin. The Sukh-Beas Nallah follows the border line between the canal systems on its right and left along the lowest contours (Fig. 4). Presently, the Sukh-Beas has no catchment across Indian borders and only carries drainage water of the adjacent lands of Bari Doab starting from Kasur district (Basharat 2016). The Sukh-Beas catchment covers parts of the district of Lahore, Kasur, Sahiwal, Vehari and Multan. Presently, most of the Sukh-Beas bed remains dry except the upper reaches receiving drainage from adjacent villages and factories, particularly the effluent from different industries, e.g., Abdullah Sugar Mill near Suffa Village (d/s of BS Link canal). The flow reduces in the $\mathrm{d} / \mathrm{s}$ direction due to infiltration under the bed (Basharat 2016).

\section{Methodology and field data analysis}

The study consists of both desk work and field surveys. The desk work mainly included data analysis regarding river flows (1977-2015), particularly discharges at various barrages for assessment of available flood flows. The field surveys were carried out for measuring channel cross sections, and in situ infiltration tests were conducted in the bed of Sukh-Beas channel at appropriate locations.

\section{Estimation of flood water availability in the river system}

In hydrology, the annual exceedance probability (AEP) is the chance or probability of a rainfall or flooding event occurring annually and is usually expressed as a percentage. For example, an event having a 1 in 100 chance of occurring in any single year would be having and AEP of $1 \%$. Similarly, any discharge value having an AEP of 50\% will have 50 in 100 chances of occurrence, i.e., the event is expected to occur every second year. Heavy rainfall or 
flood events occur less often and will therefore have a lesser annual probability.

Estimation of potential flood flows in the river system using available discharges and corresponding flow volumes at various barrages in Ravi, Sutlej, Chenab and Jhelum rivers was carried out. Aike and Daik Nallahs could not be included in the data analysis due to the non-availability of data. The data was processed hydrologically and statistically for estimating the availability of different flood volumes and their corresponding return periods in the river system.

The 10-daily discharge data regarding downstream flows of the barrages on Sutlej, Ravi, Chenab and Jhelum rivers were collected from Chief Engineer, H\&WM (Hydrology and Water Management) of WAPDA, for the period 1976-1977 to 2014-2015. The data for the period from July to September for each year were extracted from the annual records and analyzed in Excel for the total and annual average volumes during these 3 months. For the purpose of evaluation of probability of extra discharges and volumes available at each site, the 10-daily discharges were arranged in series in descending order. Flow duration curves were drawn, and discharges were calculated at $50 \%, 65 \%$ and $75 \%$ probability of exceedance, using Eq. (1), as follows:

$F=100 * \frac{R}{N+1}$

where $F$ is the frequency of occurrence (expressed as $\%$ of time, a particular flow value is equaled or exceeded), $R$ is the Rank and $N$ is the total number of observations. Similarly, the corresponding volume at respective exceedance probability was also calculated.

\section{Sukh-Beas channel capacity assessment}

Google Earth was used for digitizing the route of SukhBeas (SB) channel as exactly as it appears on the earth's surface, using $\mathrm{kmz}$ file format. The channel was traced back till beyond Amritsar in India. The kmz file was imported and converted to shapefile in ArcMap 10.1, where it was divided into various reaches and sections. The total length of the SB channel studied is $765.3 \mathrm{~km}$, starting from BS Link canal to its outfall in Sutlej River and the remaining downstream portion till its confluence with Chenab River, after passing under the SMB Link canal as a siphon (Basharat 2016).

\section{Leveling survey}

Leveling surveys were carried out at 25 locations (Figs. 4, 5) to draw cross sections along the channel at appropriate intervals. Minors/distributaries falling close to the SB channel were selected, and their bed levels served as benchmarks. Wherever bed levels were found to be out of shape significantly, the full supply level (FSL) marks served as the benchmarks. These benchmark data were obtained from GIS attribute data of irrigation channel shapefiles prepared for Punjab Irrigation Department by GEO Research Consultants. The survey was carried out with the help of dumpy level (Fig. 5). The data were processed in Excel, and graphs were drawn for accuracy checks before using the cross-sectional data in HEC-RAS model. This helped in defining the channel prism and the assessment of the discharge carrying capacity using HEC-RAS model. Locations of these 25 cross sections along the Sukh-Beas channel are given in Table 1.

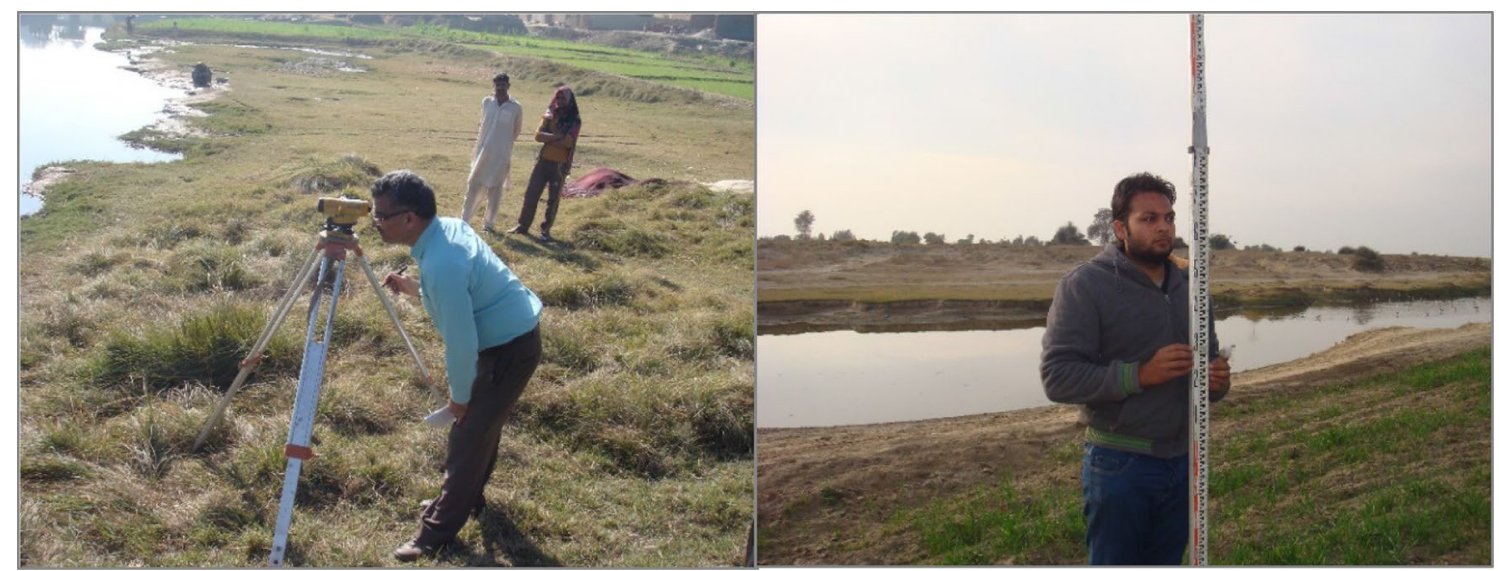

Fig. 5 Leveling survey being carried out (near Muhammad Pura village) 
Table 1 Cross sections taken along the length of Sukh-Beas channel

\begin{tabular}{|c|c|c|c|c|}
\hline \multirow[t]{2}{*}{ Channel reach } & \multirow[t]{2}{*}{$\mathrm{X}$-sec no. } & \multicolumn{2}{|c|}{$\begin{array}{l}\text { Coordinates of bench- } \\
\text { mark }\end{array}$} & \multirow[t]{2}{*}{ Benchmark (BM) at the tail of } \\
\hline & & Latitude & Longitude & \\
\hline \multirow{15}{*}{$\begin{array}{l}\text { BS Link to Sukh-Beas } \\
\text { diversion point to Sukhnai } \\
\text { Outfall }\end{array}$} & $\mathrm{X}-1$ & 30.849552 & 73.872632 & Gidpur Mr. of Chunian Disty \\
\hline & $X-2$ & 30.830873 & 73.859425 & Sial Disty from BS Link-II \\
\hline & $\mathrm{X}-3$ & 30.785443 & 73.800084 & Bejanpur Dist \\
\hline & $\mathrm{X}-4$ & 30.734987 & 73.671713 & BM at head regulator of Purja sub-minor on Qila Jawand Singh Minor \\
\hline & $\mathrm{X}-5$ & 30.685419 & 73.515224 & BM at tail of Qila Jawand Singh Minor \\
\hline & $\mathrm{X}-6$ & 30.685597 & 73.457981 & $\mathrm{BM}$ at the tail of $2 \mathrm{~L} / \mathrm{LBDC}$ distributary \\
\hline & $\mathrm{X}-7$ & 30.617052 & 73.401406 & $\begin{array}{l}\text { Near tail of Alwardi Minor of Nehranwala Disty. Survey could not be con- } \\
\text { nected due to long distance. Approximated from Google and adjusted for } \\
\text { error }\end{array}$ \\
\hline & $\mathrm{X}-8$ & 30.537615 & 73.244096 & $\mathrm{BM}$ is canal bed, just $\mathrm{u} / \mathrm{s} \mathrm{H} / \mathrm{R}$ of at the tail of Ladhwanga distributary \\
\hline & $\mathrm{X}-9$ & 30.536570 & 73.174911 & Tail of Channi Minor \\
\hline & $\mathrm{X}-10$ & 30.468958 & 73.056926 & Tail of 1L/9L/LBDC \\
\hline & $\mathrm{X}-11$ & 30.433763 & 72.956461 & 4L/9L/LBDC, about $1.68 \mathrm{~km}$ away from Sukh-Beas \\
\hline & $\mathrm{X}-12$ & 30.409175 & 72.861206 & $5 \mathrm{~L} / 9 \mathrm{~L} / \mathrm{LBDC}$ \\
\hline & $\mathrm{X}-13$ & 30.364936 & 72.795693 & Bed of tail of 9L Disty $(u / s$ of $H / R)$ of LBDC \\
\hline & $\mathrm{X}-14$ & 30.298452 & 72.645882 & $\mathrm{BM}$ at tail of $1 \mathrm{R} / 2 \mathrm{BR}$ Minor of Pakpattan canal \\
\hline & $\mathrm{X}-15$ & 30.261146 & 72.625669 & BM at tail of 2BR Minor of Pakpattan canal \\
\hline Sukhnai drain & $\mathrm{X} 16$ & 30.036202 & 72.574611 & BM is 7 inches above the FSL at the tail (RD: $331+650$ ) of Khadir Branch \\
\hline \multirow[t]{2}{*}{ Sukhnai outfall to SMB Link } & $\mathrm{X}-17$ & 30.226037 & 72.587507 & FSL at RD 6 of Pakhi distributary of Pakpattan Canal \\
\hline & $\mathrm{X}-18$ & 30.159466 & 72.302212 & BM at tail of 5R Disty of Pakpattan Canal \\
\hline \multirow{7}{*}{$\begin{array}{l}\text { SMB Link to Chenab River } \\
\text { near Jalalpur Pirwala }\end{array}$} & $\mathrm{X}-19$ & 30.162147 & 72.192675 & FSL of New Alipur Minor at its head \\
\hline & $\mathrm{X}-20$ & 30.101103 & 72.132353 & Tail of 1L Minor of New Alipur distributary \\
\hline & $\mathrm{X}-21$ & 30.077221 & 71.967003 & $\mathrm{BM}$ is the bed level of $2 \mathrm{~L}$ Disty of $10 \mathrm{R}$ \\
\hline & $\mathrm{X}-22$ & 29.999436 & 71.841043 & $\mathrm{BM}$ is the bed of $7 \mathrm{R}$ disty of Pakpattan canal \\
\hline & $\mathrm{X}-23$ & 29.865142 & 71.689256 & $\mathrm{BM}$ is the FSL of at tail of Qutabpur Disty \\
\hline & $X-24$ & 29.944610 & 71.613993 & bed at tail of $5 \mathrm{R}$ minor of $10 \mathrm{R}$ Disty/LBDC \\
\hline & $\mathrm{X}-25$ & 29.793770 & 71.504432 & $\mathrm{BM}$ is the bed of $1 \mathrm{R}$ sub-minor of $2 \mathrm{~L}$ minor \\
\hline
\end{tabular}

For channel discharge capacity assessment purposes, HEC-RAS model was built as explained in the following section.

\section{HEC-RAS modeling for capacity assessment}

HEC-RAS version 5.0 was used for discharge carrying capacity assessment of the channel. Three separate steadystate models were developed for the three reaches (as shown in Fig. 4), i.e.,

- BS Link to Sukhnai outfall into the Sutlej River near Luddan;

- Sukh-Beas diversion near Burewala to SMB Link; and

- SMB Link to Chenab River.

The geometry file for HEC-RAS was developed using RAS Geometry and RAS Mapping tools of HEC-GeoRAS in ArcMAp 10.1. Cross sections are one of the key inputs to HEC-RAS. Cross-sectional points as surveyed in the field were converted to station points depending upon their respective locations. All the cross-sectional data were copied from Excel into the Cross Section Data Editor of HEC-RAS. All the cross sections were entered from left to right while looking in downstream direction of the Sukh-Beas channel. For such earthen channels, n values, as given in Chow (1959), range from 0.022 to 0.033 . Initially, the three river reaches were analyzed using observed geometric/cross-sectional data. Afterward, additional cross sections were added by interpolation, wherever required. Different discharges were tried for the three reaches modeled, until a suitable discharge was accommodated in the respective reach.

\section{Infiltration tests and borehole strata}

Keeping in view the heterogeneity of the alluvium in the area, ten infiltration tests were conducted in the channel bed using a double-ring infiltrometer, at ten different locations 
Table 2 Division of Sukh-Beas into reaches and their lengths

\begin{tabular}{lc}
\hline Reach & Length (m) \\
\hline BS Link to Okara-Depalpur rd & 80,484 \\
Okara-Depalpur rd to Okara-Pakpattan rd & 74,868 \\
Okara-Pakpattan rd to Sahiwal-Arifwala rd & 79,406 \\
Sahiwal-Arifwala rd to Sheikh Fazal & 57,546 \\
Sheikh Fazal to Sukhnai diversion & 43,238 \\
Sukhnai drain & 63,936 \\
Sukhnai diversion to SMB Link & 129,584 \\
SMB Link to Jahanian & 62,660 \\
Jahanian to Basti Malook & 75,075 \\
Basti Malook to Chenab River & 98,493 \\
Total & 765,290 \\
\hline
\end{tabular}

Table 3 Adopted hydraulic conductivity values for sediments (Ritzema 1994)

\begin{tabular}{llll}
\hline Sr. \# & Material type & $K$ (m/day) \\
\cline { 3 - 4 } & & Minimum & Maximum \\
\hline 1 & Clay soils (surface) & 0.01 & 0.5 \\
2 & Deep clay beds & $10^{-8}$ & $10^{-2}$ \\
3 & Silt & 0.5 & 1 \\
4 & Loam soils & 0.1 & 1 \\
5 & Fine sand & 1 & 5 \\
6 & Medium sand & 5 & 20 \\
7 & Coarse sand & 20 & 100 \\
8 & Gravel & 100 & 1000 \\
9 & Sand and gravel mixture & 5 & 100 \\
\hline
\end{tabular}

well distributed across the course of the channel. All the tests were performed either in the center of the channel (in case of dry bed) or at the side of the flowing water in the channel. This was done to make sure that the time required for performing the test is the minimum possible, and the final infiltration rate achieved represents saturated conditions below the infiltrometer. So, this would help in accurately estimating groundwater recharge potential in the bed of Sukh-Beas channel. Keeping in view the large variation in infiltration rates as observed during the field tests, as well as well established heterogeneity of the aquifer under Bari Doab, lithologic data of boreholes collected during 1950s and 60s were used, as detailed in WAPDA (1980). The test drilling/boreholes map from WAPDA (1980) was scanned and georeferenced. The boreholes falling along the SukhBeas channel were digitized along with the logs data.

Altogether, the total channel length from BS Link canal to Sukhnai outfall and the remaining portion joining River Chenab was divided into ten reaches, as given in Table 2 . The depth of the Sukh-Beas channel varies from about $3 \mathrm{~m}$ in the upstream to about $1 \mathrm{~m}$ in the downstream direction.
The lithology of sediments (e.g., clay, silt, sand or a mix of these) for $3 \mathrm{~m}$ thickness below the aforementioned channel depths was noted from the logs of boreholes falling adjacent to the Sukh-Beas channel. So, the K values for the bed materials at respective locations were based on the lithology of material, and the values reported in the literature for these materials (Ritzema 1994, Table 7.2 page: 237), as given in Table 3. Wetted perimeter of all the cross sections falling in respective reaches was obtained from the respective HECRAS model for the full capacity simulated discharge, and an average value was obtained for each reach. The average wetted perimeter of the channel within the respective reach was multiplied with its length to get the total wetted area $\left(\mathrm{m}^{2}\right)$ through which the recharging water would be passing.

The infiltration capacity (seepage) of Sukh-Beas channel was estimated using Darcy's Law:

$Q=K i A$

where $Q$ is the seepage rate, $K$ is the coefficient of permeability, $i$ is the hydraulic gradient and $A$ is the wetted area causing seepage.

Water table under the Sukh-Beas channel is deep enough (varies from $6 \mathrm{~m}$ to more than $20 \mathrm{~m}$ ) that the channel seepage can be assumed as not connected to the water table. According to the theory of fluid mechanics, for a vertical water column, the value of Hydraulic Gradient $i$ can be taken as unity. The flow depth above the bed was taken as extra head over the bed causing seepage. Therefore, hydraulic gradient (i) was calculated as "assumed bed thickness $(2 \mathrm{~m})+$ flow depth" divided by "assumed bed thickness ( $2 \mathrm{~m})$."

\section{Estimation of flood water availability for barrages in Punjab}

Discharges and volumes at 50\%, 65\% and 75\% AEP (annual exceedance probability during July to September) at different barrages on Jhelum, Chenab, Ravi and Sutlej rivers and releases below Kotri Barrage are given in Table 4. At the Punjnad Barrage, where the extra flows from Jhelum, Chenab, Ravi and Sutlej join together, the downstream discharge and volume at 50\% AEP were 31,100 cfs and 10.28 MAF, respectively. At $65 \%$ AEP, the corresponding values were $13,200 \mathrm{cfs}$ and 10.86 MAF. Similarly, at $75 \%$ AEP, discharge was $7000 \mathrm{cfs}$ and volume was $11.04 \mathrm{MAF}$. It means there is only a little addition in volume of $0.76 \mathrm{MAF}$ when probability of $75 \%$ is taken instead of $50 \%$. Thus, $50 \%$ exceedance probability is dependable instead of $75 \%$ or $65 \%$. Therefore, a volume of 10.28 MAF is available at Punjnad Barrage which can be utilized for groundwater recharge subject to its appropriate management during its routing in the river system.

At Balloki Barrage, discharge at $50 \%$ probability of exceedance (during July-September) was $9300 \mathrm{cfs}$, and the

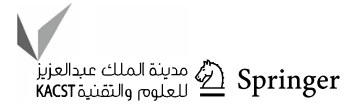


Table 4 Discharges and volumes during July-September (1976-1977 to 2014-2015), with their annual exceedance probability, at barrages

\begin{tabular}{|c|c|c|c|c|c|c|c|c|c|}
\hline \multirow[t]{2}{*}{ Flows at } & & \multicolumn{2}{|c|}{$\begin{array}{l}\text { Volume (MAF) (1976-1977 } \\
\text { to 2014-2015) }\end{array}$} & \multicolumn{3}{|c|}{$\begin{array}{l}\text { Discharge (cfs) at frequency of } \\
\text { exceedance }\end{array}$} & \multicolumn{3}{|c|}{$\begin{array}{l}\text { Volume (MAF/year) at } \\
\text { frequency of exceedance }\end{array}$} \\
\hline & & Total & Annual average & $50 \%$ & $65 \%$ & $75 \%$ & $50 \%$ & $65 \%$ & $75 \%$ \\
\hline \multirow[t]{3}{*}{ Sutlej } & Islam $\mathrm{d} / \mathrm{s}$ & 56.9 & 1.50 & 1000 & 200 & 0 & 1.48 & 1.50 & 1.50 \\
\hline & Sulemanki d/s & 76.0 & 2.0 & 3600 & 1700 & 800 & 1.90 & 1.97 & 1.99 \\
\hline & Sutlej component at Sulemanki above & 70.5 & 1.85 & 1200 & 0 & 0 & 1.84 & 1.85 & 1.85 \\
\hline \multirow[t]{3}{*}{ Ravi } & Sidhnai d/s & 79.6 & 2.0 & 5700 & 3300 & 1800 & 1.89 & 2.02 & 2.06 \\
\hline & Balloki d/s & 109.6 & 2.88 & 9300 & 5600 & 3400 & 2.53 & 2.74 & 2.83 \\
\hline & Ravi component at Balloki above & 101.2 & 2.66 & 6900 & 4100 & 2500 & 2.42 & 2.58 & 2.64 \\
\hline \multirow[t]{3}{*}{ Chenab } & Trimmu d/s & 402.8 & 10.6 & 31,800 & 15,000 & 7600 & 9.61 & 10.26 & 10.46 \\
\hline & Punjnad d/s & 423.7 & 11.15 & 31,100 & 13,200 & 7000 & 10.28 & 10.86 & 11.04 \\
\hline & Qadirabad d/s & 310.7 & 8.18 & 29,200 & 15,700 & 10,600 & 7.14 & 7.78 & 8.01 \\
\hline Jhelum & Rasul d/s & 147.8 & 3.89 & 8200 & 3700 & 1200 & 3.68 & 3.84 & 3.88 \\
\hline Indus & Kotri d/s & 948.8 & 24.97 & 78,600 & 37,200 & 17,100 & 22.64 & 24.28 & 24.75 \\
\hline
\end{tabular}

corresponding volume going downstream of Balloki Barrage was 2.53 MAF. Also, the corresponding figures for Sidhnai downstream were 5700 cfs and 1.89 MAF. Thus, a substantial volume of water is available at these two barrages which can be diverted to Sukh-Beas channel for groundwater recharge during July to September. Even excluding half of the discharge flowing downstream of the Balloki Barrage for diversion to Cholistan area, through BS Link canal (currently being planned by the Punjab Irrigation Department), half of this volume, i.e., 1.26 MAF, would still be available for diversion to Sukh-Beas channel. However, these meager flood flows available in Ravi River can be substantiated by diverting extra flood flows available in Chenab and Jhelum rivers.

This is technically feasible because excessive flood flows are available in Chenab River as compared to Jhelum River. In this regard, Table 4 gives that below Qadirabad Barrage (Chenab River), available discharge at $50 \%$ and $75 \%$ exceedance probability was $29,200 \mathrm{cfs}$ and $10,600 \mathrm{cfs}$, respectively. The corresponding downstream flow volumes were 7.14 and 8.01 MAF, respectively. Also, at Trimmu Barrage, available discharge at $50 \%$ and $75 \%$ exceedance probability was $31,800 \mathrm{cfs}$ and $7600 \mathrm{cfs}$, respectively; the corresponding flow volumes were 9.61 and 10.46 MAF, respectively. However, extra flood water available at Rasul Barrage (Jhelum River) being $8200 \mathrm{cfs}$ and $1200 \mathrm{cfs}$ at $50 \%$ and $75 \%$ exceedance probability, with corresponding flow volumes being 3.68 and 3.88 MAF, respectively, is considerably less because the flood flows in its catchment are regulated by the Mangla Barrage for irrigation and power generation.

Thus, the flows in Ravi River can be further enhanced by remodeling the two existing link canals between Chenab and Ravi rivers, i.e., Qadirabad-Balloki and Trimmu-Sidhnai. Thus, enhancing the capacities of link canals would further help in diverting the extra flood flows available in Chenab
River to Ravi at Balloki and Sidhnai barrages. From the Ravi River, these extra flows would be diverted to Sukh-Beas channel through Balloki-Sulemanki and Sidhnai-Mailsi Link canals.

In order to make sure that the extra flood flows below Punjnad Barrage are not being utilized in Lower Indus, the flows below Kotri Barrage were also analyzed. The results show that extra releases going downstream of Kotri Barrage were $78,600 \mathrm{cfs}$ and $17,100 \mathrm{cfs}$ at $50 \%$ and $75 \%$ exceedance probability, with corresponding flow volumes being 22.64 and 24.75 MAF, respectively. Also, the probability of 10,000 and 5000 cfs below Kotri Barrage remained as $79.4 \%$ and $84.5 \%$, respectively, during these 3 months. Thus, all these statistics at different barrages indicate that the releases below Punjnad Barrage remain as extra flood water during the 3 months, i.e., July-September. The months can be ranked as August, July and September in decreasing order of flows.

Again, the 10-daily discharges flowing downstream of the respective barrages were arranged in series in descending order. AEP curves on 10-daily flow basis were also drawn for the individual barrages, i.e., Sutlej component above, Balloki component above, Qadirabad d/s, Trimmu $\mathrm{d} / \mathrm{s}$, Punjnad $\mathrm{d} / \mathrm{s}$ and Kotri d/s, to check further distribution of available flows within July to September, as explained below (Fig. 6).

- For Qadirabad Barrage, minimum monthly flows were available during September, as compared to July and August. Also, minimum flows were observed during the last 10 days of September. The months can be ranked as August, July and September in decreasing order of flows.

- Similar trends are observed for the flows for Indian-flow components of Ravi River observed at Balloki above. Also, maximum flows were observed during the period 


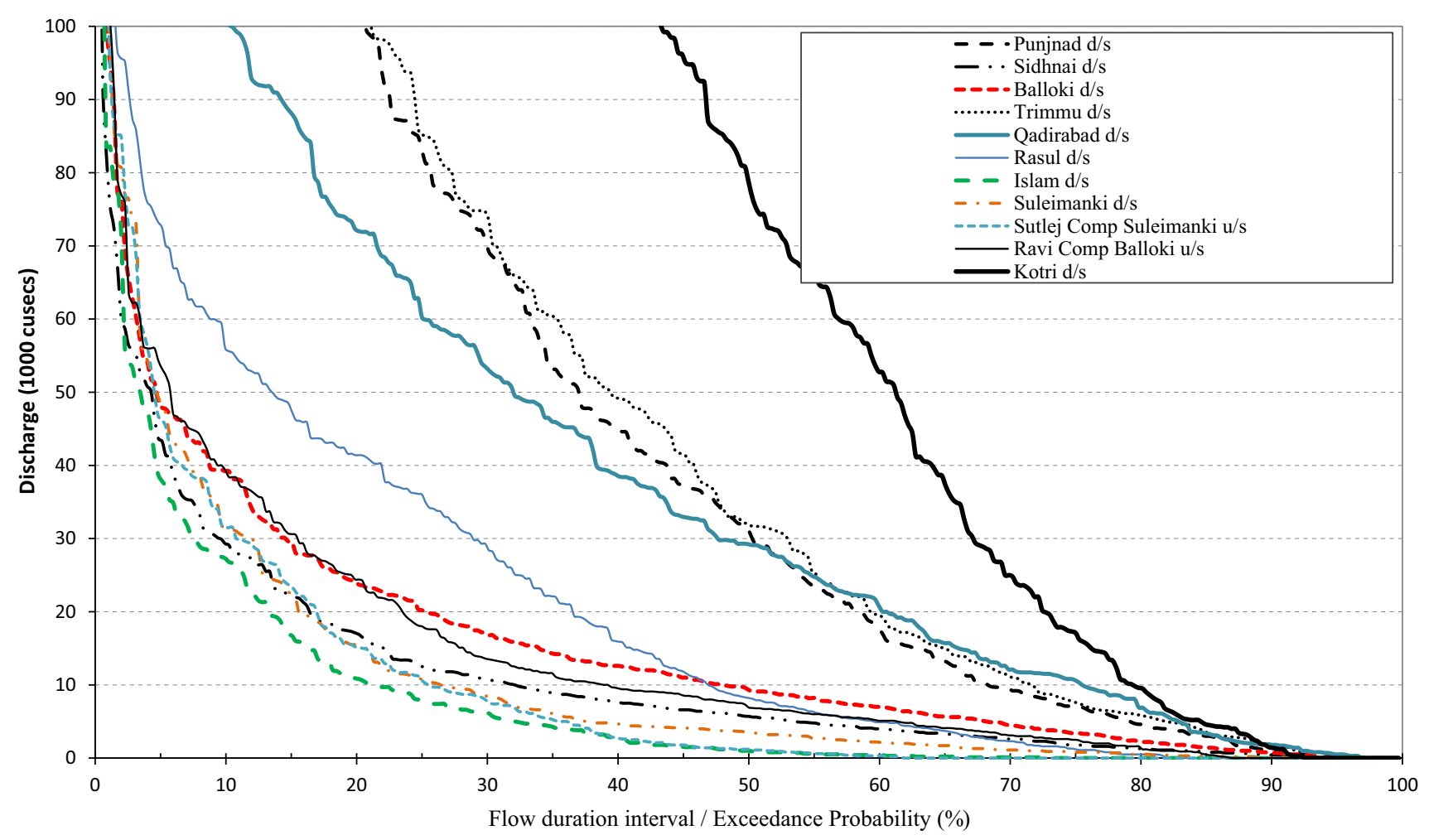

Fig. 6 Flow duration curve, representing discharges (1976-1977 to 2014-2015) at various barrages in Indus River system

from July 21 to August 31, i.e., during the last 11 days of July, and the whole month of August. Minimum flows were observed during the first 10 days of July and the last 10 days of September. Here again, the months can be ranked as August, July and September in decreasing order of flows.

- However, trends were a little different for the flows for Indian-flow component of Sutlej River observed at Sulemanki above. Here, the months are ranked as August, September and July in decreasing order of flows. Flows were maximum from August 01 to September 20. This is due to the fact that India tries to fill its available reservoir to the maximum possible as early as possible and then spills extra water during the rest of the monsoon.

- Releases below Kotri Barrage also have a similar trend to the Sutlej River component above Sulemanki, i.e., monthwise flows rank from August, September and July, in decreasing order. Here again, the extra flows after filling of Mangla and Tarbela are released late during the remaining monsoon period.

\section{Modeling results for capacity assessment}

Assuming that Sukh-Beas (SB) channel exists along all its course up to River Chenab, with same sections as observed in upstream and downstream sides of the reaches, the HECRAS model has simulated its discharge capacity as 113.27 cms (4000 cfs) for BS Link to its outfall in Sutlej River near Luddan, SMB Link to SB divergence point as 1000 cfs and $43 \mathrm{~m}^{3} / \mathrm{s}$ (1518 cfs) for SMB Link to its confluence with Chenab River. Normal depth boundary condition (with energy slope of 0.000114 ) was used at its section. The energy slope is used to compute normal depth from the given flow rate. The model was run several times, and various discharge profiles were simulated. However, after substantial rehabilitation of the channel, particularly in a reach of about $15-20 \mathrm{~km}$, lying exactly on north of Vehari City, a discharge of $28 \mathrm{cms}$ (1000 cfs) can also be diverted to SB diversion to SMB Link canal.

\section{SMB Link canal to Chenab River, existing conditions of the channel}

The total length of this reach is $236.2 \mathrm{~km}$, and the channel capacity successively reduces in downstream direction. The channel gets shallow and less deep toward the Chenab River. The channel is much wider and deeper till it continues with the New Alipur Disty. However, due to non-function of the channel, the local government and people have constructed small metaled and Kacha roads across the channel at few places. However, under major road and rail links, 
the bridges are of sufficient capacity to pass a discharge of about $4000 \mathrm{cfs}$, as the escape structure of SMB Link canal (RD: 150970) is already designed to pass $4000 \mathrm{cfs}$, with a peak possible discharge of $5500 \mathrm{cfs}$. The channel is almost in good shape and section till Garha More-Nawan Chowk road. After that, neighboring farmers have started cultivating the channel, however without disturbing the bed level. After this, till Basti Malook, farmers at a few places have disturbed the channel section. After Basti Malook, bridges are there on main roads, but the farmers have extensively cultivated the channel bed, till its confluence with Chenab River. That is why the channel is not in good shape. However, still the channel route is identifiable and can be rehabilitated for channelization and releasing flood water, but would necessarily require digging of its bed by about $1 \mathrm{~m}$.

A steady-state model was developed for the reach, starting with a discharge of $43 \mathrm{~m}^{3} / \mathrm{s}$ (1518 cfs, Fig. 7). Normal depth boundary condition (with energy slope of 0.0000875 ) was used. The HEC-RAS has the capability to perform channel modification on an existing channel geometry. Now the model was run by lowering the bed level by $1 \mathrm{~m}$ from the third section (2L/10R/LBDC) to Chenab River, but without widening the section. It is seen that with deepening of the channel bed by $1 \mathrm{~m}$, the Sukh-Beas can accommodate a discharge of $43 \mathrm{~m}^{3} / \mathrm{s}$ (1518 cfs) up to its confluence with Chenab River as shown in Fig. 7.

\section{Recharge estimation of Sukh-Beas channel}

The water table below SB channel is more than $6 \mathrm{~m}$, and therefore it can be assumed that the SB flow is not directly connected with the groundwater or the saturated zone. Thus, channel seepage in SB would be governed by hydraulic properties of the channel bed and bank and the hydraulic gradient which would necessarily be vertical. Flow through porous media is governed by Darcy's law expressed by Eq. (2) (Rushton and Redshaw 1979), and the amount of seepage through an area $A$ is expressed by Eq. (3) (Cedergren 1988):

$v=k i$

$Q=K i A$

where $v$ is the seepage velocity, $k$ the hydraulic conductivity or permeability, $i$ the hydraulic gradient equal to the net head over the area $A$ divided by the thickness of a soil sample, $Q$ the seepage discharge rate, $K$ the coefficient of permeability and $A$ the wetted area of the channel causing seepage. Thus, the infiltration capacity (seepage) of Sukh-Beas channel can be estimated using Eq. (3). With prevailing groundwater levels varying between 10 and $25 \mathrm{~m}$ below the NSL, seepage flow beneath SB bed can be certainly assumed as vertical. The flow depth above the bed was taken as extra head over the bed causing seepage. Therefore, hydraulic gradient (i) was calculated as "assumed bed thickness $(2 \mathrm{~m})+$ flow depth" divided by "the assumed bed thickness $(2 \mathrm{~m})$."

\section{Recharge estimation}

The ten infiltration tests conducted in the Sukh-Beas channel bed gave wide ranging results as given in Table 5, i.e., varying from 2.4 to $144 \mathrm{~cm} /$ day, with infiltration rates generally increasing in downstream direction. Also, the ten infiltration tests conducted along a total SB length of $765 \mathrm{~km}$ were too less in number. Seepage from SB channel is linked to the upper soil strata. SB channel bed is about 2-3 m (10 ft) below the surrounding NSL in the reach from BS Link to

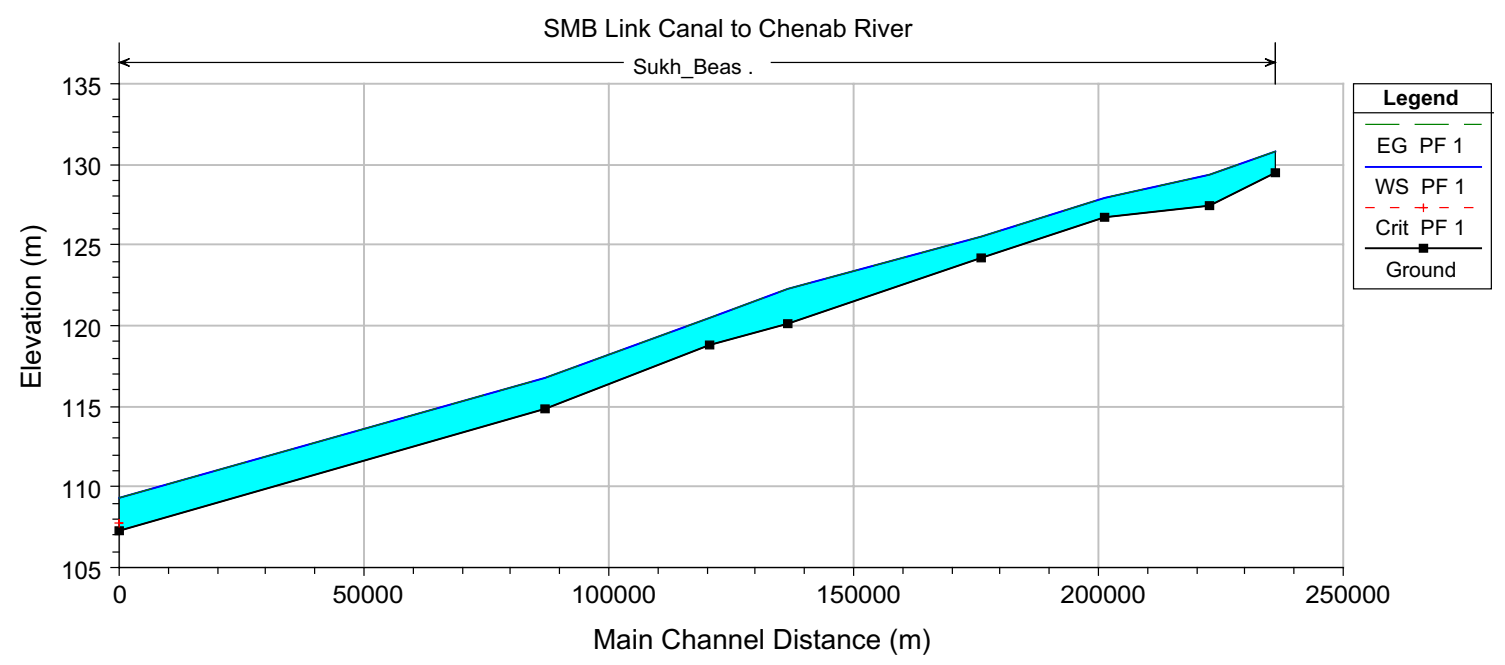

Fig. 7 L-section of SMB Link to Chenab River profile, $Q=43 \mathrm{~m}^{3} / \mathrm{s}$, as shown by HEC-RAS model 
Table 5 Infiltration test conducted in the bed of Sukh-Beas channel

\begin{tabular}{|c|c|c|c|c|}
\hline Test no. & Location & Coordinates & $\begin{array}{l}\text { Infiltra- } \\
\text { tion }(\mathrm{cm} / \\
\text { day) }\end{array}$ & Remarks \\
\hline 1 & Muhammad Pura village & E:73.873464; N:30.846423 & 2.4 & $\begin{array}{l}\text { Test performed in soaked area near to flowing } \\
\text { water }\end{array}$ \\
\hline 2 & Depalpur-Okara road X-ing & E:73.607941; N:30.720375 & 7.2 & Test performed inside berm of the channel \\
\hline 3 & $\begin{array}{l}\text { Viyah Pattan (Pakpattan-Gamber road } \\
\text { X-ing) }\end{array}$ & E:73.332281; N:30.539201 & 29.0 & Test performed along side the flowing water \\
\hline 4 & $\begin{array}{l}\text { AR Bridge RD: } 664+500 \text { of Sukhnai drain } \\
\text { (Pakpattan-Sahiwal road X-ing) }\end{array}$ & E:73.177023; N:30.555544 & 2.4 & $\begin{array}{l}\text { Test performed inside the channel bed with } \\
\text { flowing water }\end{array}$ \\
\hline 5 & $\begin{array}{l}\text { On the other side of Chak No. 119/9L, near } \\
\text { Sahiwal-Arifwala road and } 1.3 \mathrm{~km} \mathrm{~d} / \mathrm{s} \text { of } \\
\text { 1L/9L Minor }\end{array}$ & E:73.050685; N:30.458615 & 144 & $\begin{array}{l}\text { Channel bed was totally dry and consisting of } \\
\text { medium sand. Test could not be continued } \\
\text { for sufficient time }\end{array}$ \\
\hline 6 & Kameer & E:73.039829; N:30.420597 & 55.2 & $\begin{array}{l}\text { Test performed in channel bed with sparse } \\
\text { flow }\end{array}$ \\
\hline 7 & $\begin{array}{l}\text { Near Sheikh Fazal, at Chichawatni-Burewala } \\
\text { road }\end{array}$ & E:72.789125; N:30.342704 & 16.8 & $\begin{array}{l}\text { Channel bed was almost dry, but with sparse } \\
\text { grass }\end{array}$ \\
\hline 8 & Burewala-Vehari road X-ing & E:72.624532; N:30.138848 & 84 & $\begin{array}{l}\text { Test performed in the bed along the flowing } \\
\text { water }\end{array}$ \\
\hline 9 & Jahanian-Chowk Metla road X-ing & E:71.817499; N:30.012171 & 9.6 & The channel bed is covered with fine material \\
\hline 10 & Near Basti Malook & E:71.553217; N:29.849444 & 43.2 & Performed in the channel bed, areas is sandy \\
\hline
\end{tabular}

its diversion to Sukhnai outfall drain. However, from SukhBeas diversion to its joining with Chenab River, the bed depth varies from 1 to $2 \mathrm{~m}$ below the surrounding NSL. Thus, in order to define a representative infiltration rate for any reach was not beyond doubts due to such a high variability, as also proved from the hydrogeological investigations. Therefore, top strata of test holes conducted during 1950s and 60s falling along and near the SB channel were consulted, and the material within $3 \mathrm{~m}$ below the channel bed was listed to define hydraulic conductivity.

The detailed recharge calculations are given in Tables 6 and 7. A recharge of 330.5, 68.4, 198.6 and 210.3 cfs was estimated for BS Link to SB diversion point, SB diversion point to Sukhnai outfall in Sutlej, SB diversion point to SMB Link and SMB Link to Chenab River, respectively, with a total of $807.8 \mathrm{cfs}$ and a channel length of $765.3 \mathrm{~km}$.

\section{Steps before flood water diversion}

The SB Nallah exists right in the middle of Bari Doab where groundwater levels are the deepest and the channel is already linked to the river system through escape gates at BS and SMB Link canals. Therefore, it is worth moving toward utilizing the flood flows and recharging it to the depleting aquifer. However, certain steps need to be taken before the flood water can be released as discussed below.

\section{Escape structures}

\section{BS Link escape structure}

The SB River passes under the BS Link canals as a siphon (Fig. 8L); the BS Link also has the escape structure designed to discharge into the SB Nallah (Fig. 8R). The escape structure has eight gates. As shown in Figs. 8 and 9 (snaps taken during January 2016), gate operating motors existed some time ago on the structure, but had been stolen. Sliding channels and rollers of individual gates are intact, but would certainly need rehabilitation before these can be utilized for releasing flood water. The channel linking the escape structure to the SB Nallah and the Nallah itself is wide enough here and therefore has a sufficiently large capacity, i.e., more than $4000 \mathrm{cfs}$, the assessed capacity of the SB channel through HEC-RAS modeling.

\section{SMB Link escape structure gates}

Condition survey of the gates of the escape structure discharging into the SB Nallah Sidhnai-Mailsi-Bahawal (SMB) Link canal was carried out during January 2016 (Fig. 10). Pictures were taken for each of the six gates, and the conditions were noted (Fig. 10). Gates were found to be in good condition and functioning properly in closed position and may need minor rehabilitation/cleaning for making operational for proposed escapages to the SB channel. 


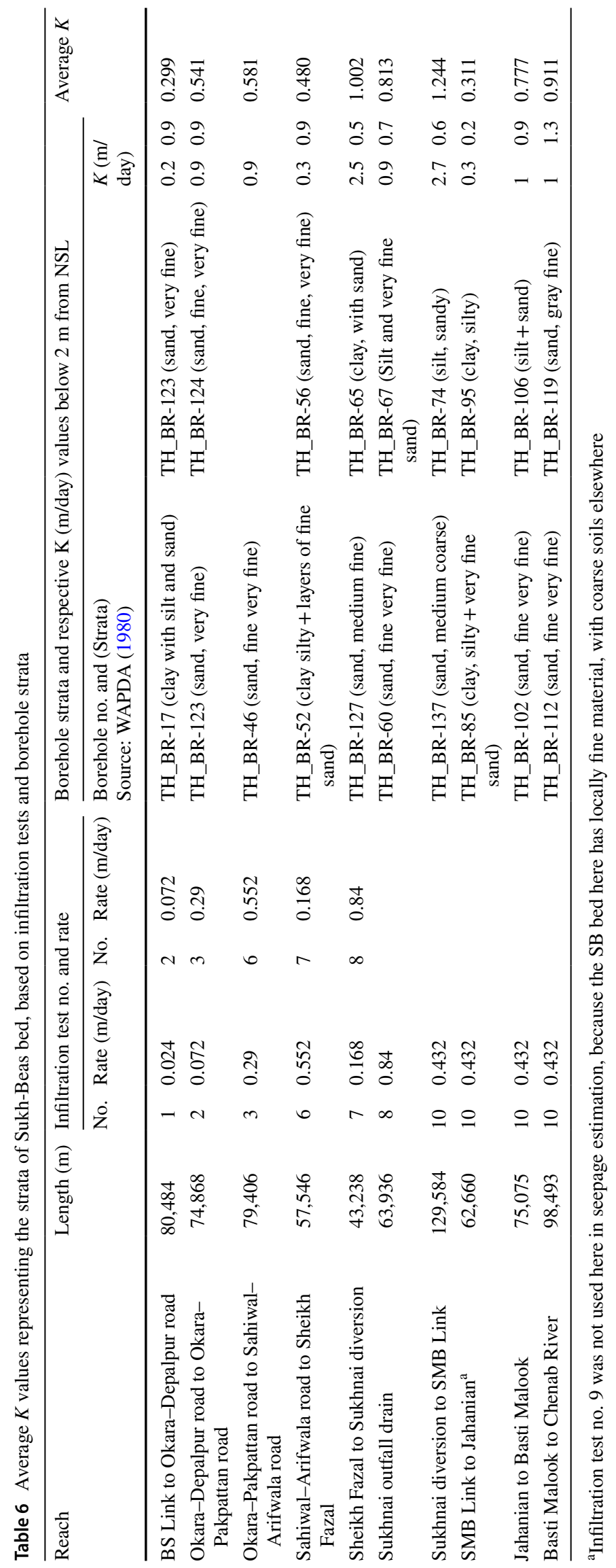


Table 7 Recharge calculations for various reaches using wetted perimeter (WP), hydraulic conductivity $(K)$ and hydraulic gradient

\begin{tabular}{|c|c|c|c|c|c|c|c|c|}
\hline \multirow[t]{2}{*}{ Reach } & \multirow[t]{2}{*}{ Length (m) } & \multirow[t]{2}{*}{ Flow depth (m) } & \multirow{2}{*}{$\begin{array}{l}\text { Reach averaged } \\
\text { wetted perimeter } \\
(\mathrm{m})\end{array}$} & \multirow{2}{*}{$\begin{array}{l}\text { Total WP } \\
\text { within the } \\
\text { reach }\left(\mathrm{m}^{2}\right)\end{array}$} & \multirow[t]{2}{*}{$K$ (m/day) } & \multirow{2}{*}{$\begin{array}{l}\text { Hydrau- } \\
\text { lic gradi- } \\
\text { ent }\end{array}$} & \multicolumn{2}{|c|}{ Estimated recharge } \\
\hline & & & & & & & $\mathrm{m}^{3} /$ day & $\mathrm{cfs}$ \\
\hline BS Link to Okara-Depalpur rd & 80,484 & 3.4 & 112.3 & 9035165 & 0.299 & 2.68 & $7,245,461$ & 83.9 \\
\hline $\begin{array}{l}\text { Okara-Depalpur rd to Okara- } \\
\text { Pakpattan rd }\end{array}$ & 74,868 & 3.7 & 61.7 & $4,616,868$ & 0.541 & 2.83 & $7,055,792$ & 81.7 \\
\hline $\begin{array}{l}\text { Okara-Pakpattan rd to Sahi- } \\
\text { wal-Arifwala rd }\end{array}$ & 79,406 & 4.1 & 43.5 & $3,450,185$ & 0.581 & 3.07 & $6,140,443$ & 71.1 \\
\hline $\begin{array}{l}\text { Sahiwal-Arifwala rd to Sheikh } \\
\text { Fazal }\end{array}$ & 57,546 & 3.9 & 38.9 & $2,238,534$ & 0.480 & 2.95 & $3,175,137$ & 36.7 \\
\hline $\begin{array}{l}\text { Sheikh Fazal to Sukhnai diver- } \\
\text { sion }\end{array}$ & 43,238 & 3.9 & 38.6 & $1,667,531$ & 1.002 & 2.95 & $4,937,409$ & 57.1 \\
\hline Sukhnai drain & 63,936 & 3.5 & 41.1 & $2,627,761$ & 0.813 & 2.76 & $5,906,541$ & 68.4 \\
\hline $\begin{array}{l}\text { Sukhnai diversion to SMB } \\
\text { Link }\end{array}$ & 129,584 & 2.3 & 49.3 & $6,385,253$ & 1.244 & 2.16 & $17,157,430$ & 198.6 \\
\hline SMB Link to Jahanian & 62,660 & 1.49 & 112.3 & $7,034,193$ & 0.311 & 1.75 & $3,816,972$ & 44.2 \\
\hline Jahanian to Basti Malook & 75,075 & 1.72 & 61.7 & $4,629,598$ & 0.777 & 1.86 & $6,693,659$ & 77.5 \\
\hline Basti Malook to Chenab River & 98,493 & 1.96 & 43.5 & $4,279,517$ & 0.911 & 1.98 & $7,706,739$ & 89.2 \\
\hline
\end{tabular}

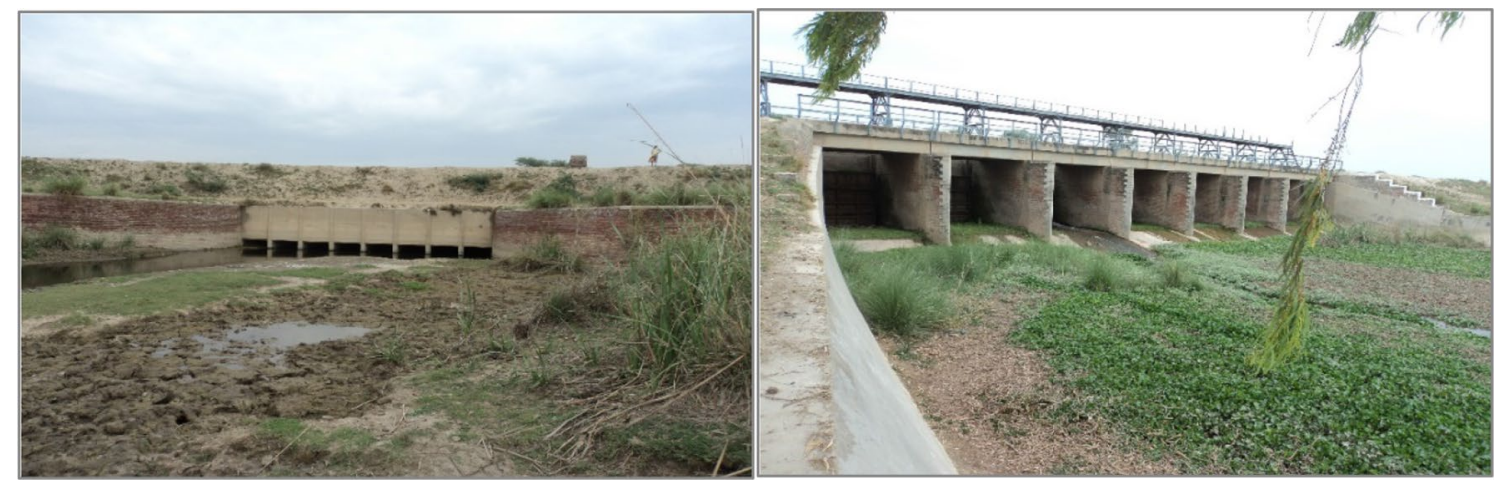

Fig. 8 Sukh-Beas River siphon under BS Link canal (L); and BS Link-I escape to Sukh-Beas (R)

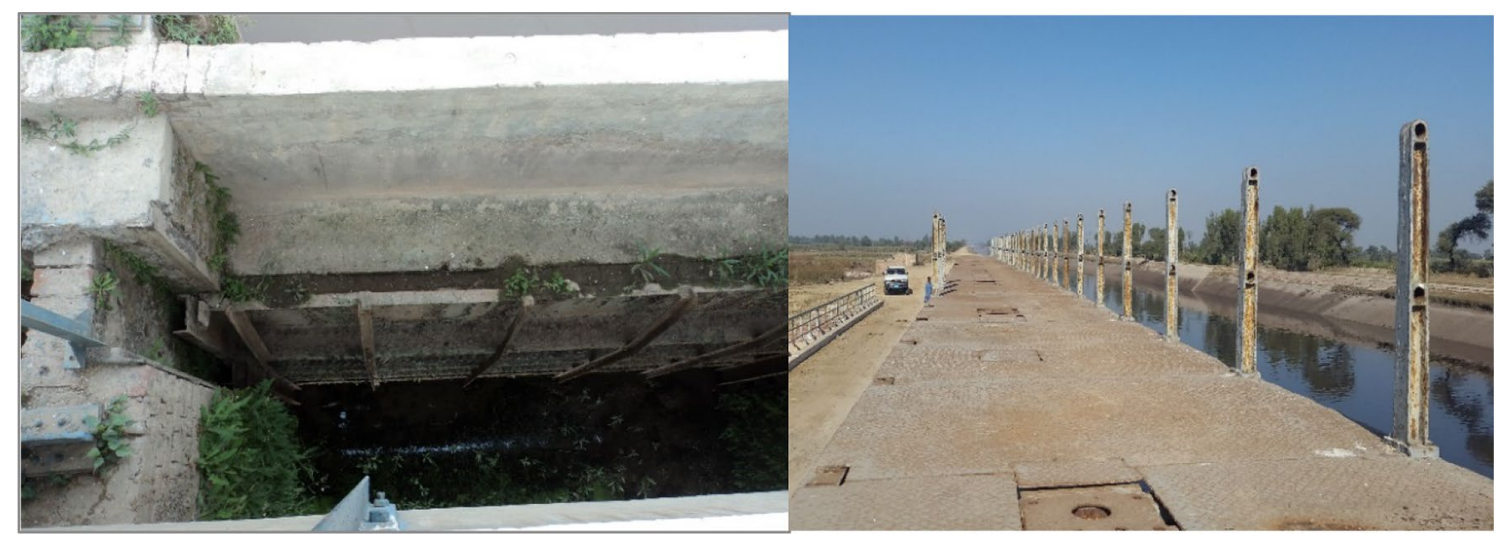

Fig. 9 One of the gates of BS Link escape (L); and hedge without operating motors (R) 

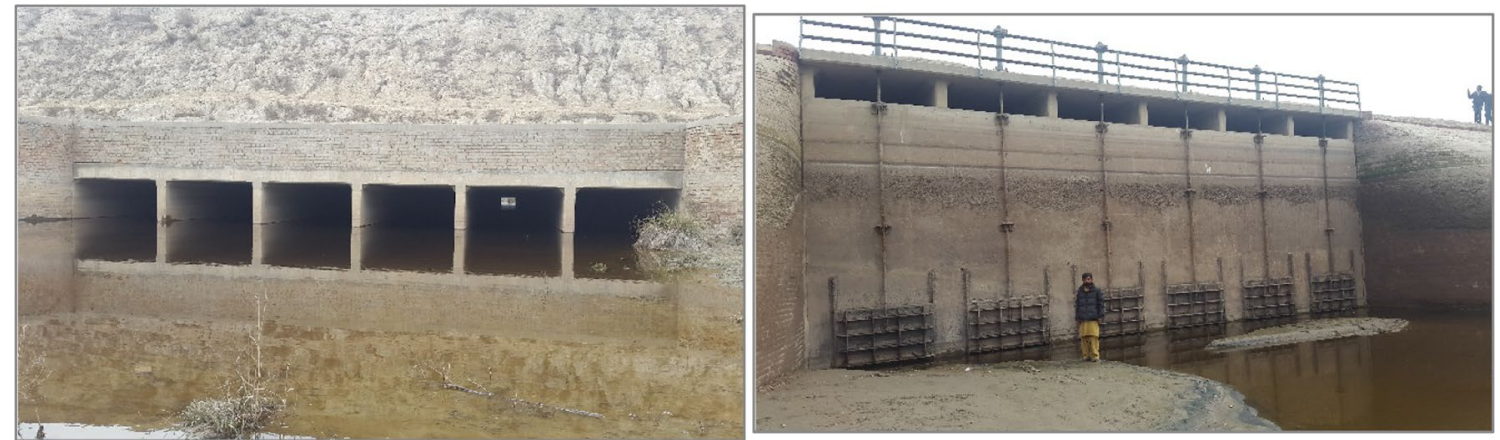

Fig. 10 SB Nullah siphon under SMB Link canal (L); and its escape gates to the siphon
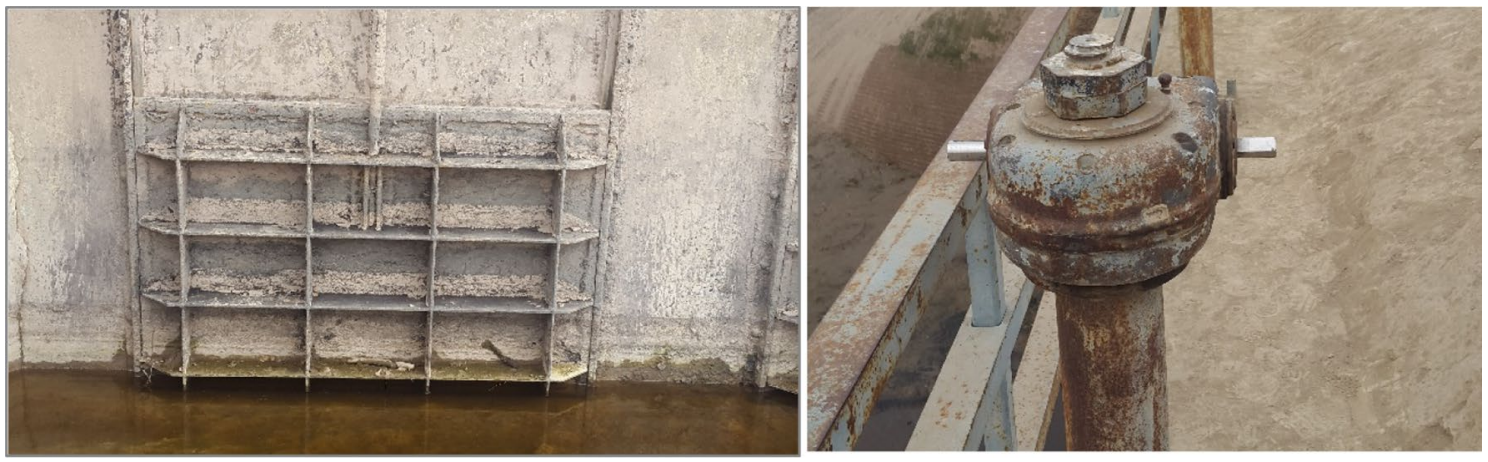

Fig. 11 SMB Link escape gate (left) and its operating mechanism

Operating mechanism (Fig. 10L) also seems to be functioning in manual manner (Fig. 11).

\section{Conclusions and recommendations}

$50 \%$ exceedance probability is more dependable, and a volume of 10.28 MAF is available at Punjnad Barrage which can be utilized for groundwater recharge subject to its appropriate management during its routing in the river system. Also, the results show that extra releases going downstream of Kotri Barrage were 78,600 cfs and 17,100 cfs at 50\% and $75 \%$ exceedance probability, with corresponding flow volumes being 22.64 and 24.75 MAF, respectively. Thus, flood flows released from Punjab through Punjnad River remain excess to the irrigation demand of Lower Indus due to extra water flowing in Indus River during July to September.

However, thousands of acres of farmland of tehsils of Kabirwala (Khanewal), Shorkot (Jhang) and Pir Mahal (Toba Tek Singh) area covering almost 200 villages are already waterlogged from the seepage occurring due to Trimmu-Sidhnai (TS) and Haveli canals. The farmers of the area already demand that the TS Link canal should not be operated for more than $4000 \mathrm{cfs}$ discharge; otherwise, underground water level rises and severely damages the crop production in the area. Therefore, conveying extra water through the TS Link without its lining is out of question. Therefore, the only option of diversion of this extra flood water to the Ravi River remains through the QB Link, UCC Link or MR Link canals. Once conveyed into the Ravi River, it can then be diverted to the SB channel through the Balloki-Sulemanki and Sidhnai-Mailsi Link canals. However, capacity enhancement of these link canals might be required, in coherence with the maximum discharge capacity of SB channel which can be accommodated for conveyance and recharge to the groundwater.

At Balloki Barrage, discharge at 50\% probability of exceedance (during July to September) was $9300 \mathrm{cfs}$, and the corresponding volume going downstream was 2.53 MAF. Also, the corresponding figures for Sidhnai downstream were $5700 \mathrm{cfs}$ and $1.89 \mathrm{MAF}$. Thus, substantial volume of water is available at these two barrages which can be diverted to SukhBeas channel during July to September. Even excluding half of the discharge flowing $\mathrm{d} / \mathrm{s}$ of the Balloki Barrage for diversion to Cholistan area, through BS Link canal (currently being planned by the Punjab Irrigation Department), half of this volume, i.e., 1.26 MAF, would still be available for diversion to Sukh-Beas channel. However, these meager flood flows 
available in Ravi River can be substantiated by diverting extra flood flows available in Chenab and Jhelum rivers.

The flood flows to the Sukh-Beas channel can be released from Balloki-Sulemanki (BS) and Sidhnai-Mailsi-Bahawal (SMB) Link canals, for recharge purpose. Therefore, it is concluded that stopping and reversing the declining groundwater tables in Bari Doab would be possible by diverting flood flows to Sukh-Beas channel. Equity among the farmers regarding groundwater availability will be improved, resulting in improved agricultural yields in the area. Specific conclusions regarding diversion of flood flow and recharge are as follows:

- Operation of the escape gates would have to be rehabilitated, especially electric motors would have to be installed for their easy and frequent operations;

- Kasur Nallah entering from India should be diverted to its old route, i.e., Sukh-Beas channel, after its rehabilitation for surface water use by the adjoining lands and groundwater recharge;

- Link canals, particularly the QB Link, Maral Ravi and UCC Link to Balloki mechanism Barrage, should be remodeled for diversion of extra flood water available in Chenab River to Balloki and Sidhnai barrages;

- All the three reaches of Sukh-Beas channel should be rehabilitated to the maximum possible level for accommodating extra flood water during wet season;

- All the three reaches of Sukh-Beas channel should be used for groundwater recharge with flood water conveyed through BS Link and SMB Link canals;

- Most of the bridges and other structures have enough capacity for passing this flood water, though very newly built bridges like the one near Muhammad Pura would need widening in order to avoid flooding of a few acres of land on upstream side;

- The SB channel crosses as level crossing with abandoned Mailsi Canal. Thus, water released in SB channel can also be ponded in Mailsi Canal;

However, capacity of the SB channel has reduced with passage of time due to encroachment of fields by the farmers toward the channel itself. Reachwise-specific conclusions and recommendations regarding the channel capacity are as follows:

- $5-10 \mathrm{~km}$ of the BS Link to Sutlej River reach of the channel would have to be widened, and its section made equivalent to the existing section of the rest of the channel;

- Trimming of the existing full section may also be needed at a few places to remove any obstacles in the channel for easy accommodation of the released flood water.

Open Access This article is distributed under the terms of the Creative Commons Attribution 4.0 International License (http://creativeco mmons.org/licenses/by/4.0/), which permits unrestricted use, distribution, and reproduction in any medium, provided you give appropriate credit to the original author(s) and the source, provide a link to the Creative Commons license, and indicate if changes were made.

\section{References}

Basharat M (2012) Spatial and temporal appraisal of groundwater depth and quality in LBDC command: issues and options. Pak J Eng Appl Sci Univ Eng Technol Lahore 11:14-29

Basharat M (2016) Developing Sukh-Beas as potential recharge site during wet years for Bari Doab. IWASRI Publication No. 305, WAPDA, Lahore

Cedergren H (1988) Seepage, drainage, and flow nets, 3rd edn. Wiley, Norwich, p 339

Chow VT (1959) Open channel hydraulics. McGraw-Hill Book Company, New York

Greenman DW, Swarzenski WV, Bennett GD (1967) Groundwater hydrology of the Punjab, West Pakistan with emphasis on problems caused by canal irrigation. West Pakistan Water and Power Development Authority, WASID Bulletin 6

Ritzema HP (1994) Drainage principles and applications, 2nd ed. ILRI Publication 16

Rushton K, Redshaw S (1979) Seepage and groundwater flow. Wiley, Norwich, p 339

WAPDA (1980) Hydrogeological data of Bari Doab (vol I). Basic data release no. 1. Directorate of hydrogeology, WAPDA, Lahore

Publisher's Note Springer Nature remains neutral with regard to jurisdictional claims in published maps and institutional affiliations. 